\title{
Bank Capital Adequacy Ratio and Bank Performance in Vietnam: A Simultaneous Equations Framework
}

\author{
Binh Thi Thanh DAO ${ }^{1}$, Kieu Anh NGUYEN ${ }^{2}$
}

Received: April 01, 2020 Revised: April 17, 2020 Accepted: May 01, 2020

\begin{abstract}
Playing an important role in developing the economy and overall developments of the country, commercial banks have to be aware of their crucial presence in order to perform well and contribute significantly. At the same time, as a place to receive deposits, banks are required to be in safe situations to avoid bankruptcy or deal with financial crises. This research seeks to identify the determinants of Capital Adequacy Ratio and Banks' performance as well as the relationship between these two dependent variables. The paper uses 128 observations of 16 Vietnamese commercial banks during the period from 2010 to 2017, with two simultaneous dependent variables CAR and ROE, and independent variables including Return on Assets, Tobin Q, Credit growth, GDP growth, Equity to Deposits, Loans to Deposits, Bank size, Cost to Income, Liquidity risk, Provision for Loan loss ratio, Non-performing loans and Inflation. The results reveal that Capital Adequacy Ratio and Banks' Performance have statistically significant relationship and Credit growth, GDP growth, Equity-to-Deposit ratio and Costto-Income ratio all have significant effects on two dependent variables. The findings of this study suggest that commercial banks should control the respective elements in order to maintain adequate level of capital and also create effective performance.
\end{abstract}

Keywords : Capital Adequacy Ratio, CAR, Performance, Macro Variables, Economic Growth, Vietnam

JEL Classification Code: G21, E01, E02, C13

\section{Introduction}

The positions of commercial banks in collaboration with developed countries can be thoroughly understood once the characteristics of developing economies are well-defined. The most outstanding characteristic of a developing country comes from low income per capital, which generally induces low savings and investment. The second most visible feature is high rate of unemployment, followed by the overpopulation, which can broaden a favorable environment for the existence of social issues. In another vein, the economy of developing countries is attached mainly with non-industrial sector and

${ }^{1}$ First Author and Corresponding Author. Vice Dean, Financial Department, Faculty of Management and Tourism, Hanoi University, Vietnam [Postal Address: Km9 Nguyen Trai, Thanh Xuan, Ha Noi, 100000, Vietnam] Email: binhdtt@hanu.edu.vn

${ }^{2}$ Financial Department, Faculty of Management and Tourism, Hanoi University, Vietnam. Email: nguyenka96@gmail.com

(c) Copyright: The Author(s)

This is an Open Access article distributed under the terms of the Creative Commons Attribution Non-Commercial License (http://Creativecommons.org/licenses/by-nc/4.0/) which permits unrestricted noncommercial use, distribution, and reproduction in any medium, provided the original work is properly cited. raw material export. Last, but not least, a developing nation possesses a relatively immature financial system, which is easy to be attacked by business cycle and is under the strong intervention of government (McConnell, Brue and Flynn, 2015). Accordingly, banks can provide intermediary function, which is served as a bridge to transfer funds from the ones who are in excess of cash to whoever is in need of money. In addition, taking advantages of infrastructures and services, commercial banks can smooth out banking transactions related to payment or foreign trade which can enhance the efficiency of export and import activities.

Since commercial banks play a very important role in the economy and the development of the country, they have to perform well and ensure their safety for any change of the economy both nationally and internationally. However, the government also needs to have policies and regulations to help the banking system do so. Among those regulations, principles on minimum capital are considered as one of the important rules that determine the safety of banks against the risk of capital shortage and bankruptcy. Another aspect that attracts significant attention from customers and investors is the banks' performance, in another word, profitability. 
Bank profit is considered as an accounting record of bank performance over a given timescale, typically a twelvemonth phase. Basically, profit of any business is determined as the excess of revenue over expenditures. Likewise, bank profit is created by lending money to whoever needs personal, business loans, mortgage and so on at higher rates than interest rates charged on customers' deposits (Australian Bankers' Association, 2012).

According to Adeusi, Kolapo, and Aluko (2014), profit maximization is a principal target of every organization that includes banks. Profitability can be determined as the excess of return on capital employed, which is obtained from the effectiveness of management and the efficiency of resources utilization at its disposal. It is essential for bank management not only to exploit its strength and opportunities, but also to tackle weakness and threats to ensure the success of a bank which is defined as how well a bank makes profits over a financial period. Because of the fact that bank profitability and the adherence of capital adequacy ratio are both crucial determinants, there are a number of researches studying the effect of one variable on the other.

However, this paper, with a different approach, will examine the two-way relationship between these two variables. The continuing parts of this paper are constructed as follows. Section 2 will discuss some existing theoretical and empirical literature on CAR ratio and bank profitability as well as factors influencing bank performance and riskweighted assets in two aspects - macro and micro variables in Vietnam. Section 3 provides the description regarding the data and methodology aspects. Section 4 emphasizes the results and discussions and Section 5 is the conclusion.

\section{Literature Review}

Recently, Vietnam has been integrated into both regional and international economies through a series of free trade agreements and being an active member of World Trade Organization (WTO), ASEAN Economic Community (AEC) and so on. This could bring, not only opportunities for Vietnamese banks to expand their scope into neighboring areas, but also challenges regarded as intensive competition among banks in region.

As illustrated by Tran and Vu (n.d.), in Vietnam, capital regulatory performance process can be divided into three periods. The first period was from 1999 to early 2006, when Government and State Banks did not regulate any minimum level of retained capital. Therefore, in 2000, with the emergence of enormously redundant bad debts, Government had to support big banks with VND12,000 billion. During the second period, from 2005 to 2009, a capital adequacy ratio of eight percent had been applied to protect the banking system against the crisis. In the third period, from 2010, the State Bank of Vietnam implemented a capital adequacy of at least nine percent despite some existed threats to the banking system and national economy due to the fact of several undercapitalized large banks. The common problem during all three terms is that even though many commercial banks can maintain capital level above eight percent as required by Basel regulations, the main banks, which comprised around three-fourths of the market share, did not follow the same direction.

In June 2006, a new framework - Basel II - was put into practice (BIS, 2018). In spite of the advancement and flexibility of Basel II, there still existed demands for reinforcing the requirement. Conforming to Amadeo (2018), the primary reason generating financial crisis in the period 2007-2008 was the loosening of bank lending regulations, not strictly regulating the quality of mortgage borrowers as well as allowing them to borrow at a premium equal to or more than the value of the mortgage houses. And when house prices started to fall continuously and there was no sign of rising again, banks became hesitate to lend out more money by receiving more unpromising mortgages, leading to a higher Libor rate and distrust among banks. Consequently, the crisis became inevitable due to weak governance and risk management. From that, it can be clearly seen that Capital Adequacy Ratio is important to banks and to a country's economy. CAR ratio is also positively influenced by Credit Growth (Ha, 2019).

Regarding the empirical studies of CAR ratio's determinants, Altunbas, Carbo, Gardener and Molyneux (2007) stated that less risk incentives and more capital would be preferred when banks became inefficient; that implied a positive relationship between risks and capital. Moreover, the researcher also ascertained the influences of a corporate sector's financial health on risk accepting ability and capital status. Additionally, after executing two models, named Market model and Regulatory model, Barrios and Blanco (2003) divided the Spanish banks' behaviors into two different groups when identifying the elements involved with capital changes. The first group of banks that had reserved capital ratio higher than requirement ratio was able to achieve a level of optimal capital structure (Market model) by adjusting the independent variables like size of bank, liquidity premium, operating expenses, variance of ROA and credit, and liquidity risks. Furthermore, the degree of capital's influences on other factors also differed to distinct banks' conditions. Rime (2001) proved this in his research on Switzerland banking system by running the duopoly model developed by Boot, Dezelan, and Milbourn (2000). Rime drew a conclusion that, with an initial low requirement rate, raising capital could lead to profit reduction at bad banks more than at good banks.

Empirical results might vary according to regional areas as well. A study by Dao and Nguyen (2016) was carried out on 20 listed Vietnamese commercial banks to find out 
what were the factors influencing capital adequacy ratio from 2011 to 2014. As a result, Return on Assets (ROA), Return on Equity (ROE) and GDP growth rate were found as determinative elements on capital. Specifically, CAR ratio had a positive relationship with ROA and a negative one with ROE and GDP growth rate, but had relatively no relation with Net Interest Margin, Capital Risk, Inflation rate, Bank Size, and so on, as first expected. An empirical study by Pham and Nguyen (2017) showed that Bank Size had insignificantly negative effect on capital. Moreover, the result of Feasible Generalized Least Squares Model (FGLS) demonstrated negative effects on capital by Deposits to Total Assets as well as ROE ratio and positive effects by Liquidity ratio, Leverage Coefficient, Loan Loss Provision to Total Loans and Total Loans to Total Assets.

On the other hand, bank performance has a certain impact on capital allocation, business expansion, the growth of both industry, and economy. Hence, a well-performing bank will benefit not only the bank itself, but also macroeconomic sectors (Bami, 2014). Normally, Return on Assets (ROA), Return on Equity (ROE) and Tobin'Q are proxy variables of performance, whereas the first two measures are accounting approach and the last one is market-based approach.

Return on Assets (ROA) is calculated by dividing Net Income by Total Assets. This is a popular indicator used by investors or financial analysts, which shows the efficiency level through the company's equivalent Return on Total Assets. As Total Assets equal the sum of Debts and Equity, ROA is meaningful to show how much a firm can turn its borrowing to profits. As demonstrated by Olarewaju and Akande (2016), there was a significant positive relationship between ROA and capital level among Nigerian banks, and one percentage change in ROA leaded to 40 percentage change in Total Equity-to-Total Assets ratio.

In accordance with the result above, Al-Tamimi and Fakhri (2013) also found a statistically strong and positive relationship between ROA and adequacy capital. However, this result is opposite to results from other studies by Berger and Bonaccorsi (2006) and Dao and Nguyen (2020). In their work, by using various tests (linear, quadratic and spline), they showed a negative association between capital and profitability. Yet, that outcome is not consistent when leverage ratio is high, which can be explained by two hypotheses - efficiency-risk hypothesis and franchise-value hypothesis. In line with the former theory, that more efficient banks prefer to pick lower capital ratios as high current profit efficiency tends to maintain high expected yields and higher expected returns from more efficient banks can be substituted for equity to serve as a cushion against risks in order to curb arisen financial distress costs. On the contrary, franchisevalue hypothesis stated that more efficient banks prefer to opt for higher capital ratio. In case of liquidation, even if no bankruptcy costs are involved, these rents would be no longer exist; therefore, more efficient banks may choose to hold relatively higher equity to prevent this situation.

Return on Equity (ROE) is computed by dividing Net Income by Total Equity. Although it is also used to measure profitability, ROE differs from ROA in that it measures the return equivalent to equity invested by shareholders. The ratio is normally preferred to be as high as possible because this means the firm is in a favorable growth and is effective at creating remarkable profitability in exchange for borrowings from equity holders. A research paper by Nuviyanti and Anggono (2014) looking at in 19 Indonesia commercial banks concluded that ROE significantly affected required capital. A research by Lee, Ning and Lee (2015) on Chinese commercial banks revealed that bank capital strongly impact banks' profit even though the effect was varied depending on bank size.

In terms of bank size-profitability relationship, there exists a variety of academic works coming with the conclusion of positive relationship between bank size and profitability. Utilizing a non-parametric analytic technique to measure the performance of Greek banks from 1997 to 1999, Halkos and Salamouris (2004) found that the volume of asset was positively correlated with bank efficiency. Furthermore, the efficiency growth in the Greek banking system was recognized following the downsizing in the number of smaller banks as a consequence of merger and acquisitions.

Regarding Cost-to-income ratio (CTI), which is the ratio of operating costs excluding bad and doubtful debt to sum of net interest income and non-interest income of the bank, was used as the indicator of risks attached with bank operations. Panel data techniques and GMM were employed to testify hypothesis and come up with the conclusion that cost to income ratio is negatively correlated with bank profitability in both long and short term (Muriithi and Muigai, 2017). To be more specific, the positive change in cost-to-income ratio coming from the increase in costs relating to staff, rental, information technology and other operating expenses or the decrease in income can reduce bank profitability.

Revell (1979) discussed some factors that should be taken into account when investigating the inflation-profitability relationship. The first consideration was that the increase in staff expenses and other operating costs at what extent compared to inflation rate. Secondly, the accuracy level in future inflation estimation, which can affect the ability of bank in managing operating expenses, depends on how mature the economy is. At the same vein, Perry (1992) also explained that once inflation rate is fully anticipated, banks can regulate properly interest rate charged on loans and deposits in order to gain higher economic profits.

In this paper, loan-to-deposit ratio, which is calculated as outstanding loans over customers' deposits, was selected as a proxy of liquidity risk. The higher the liquidity ratio, 
the more liquid and less vulnerable banks' exposure. The researcher found that the liquidity ratio was significantly positive correlated with both ROA and ROE. In other words, there is a robust negative relationship between liquidity risk and profitability. Turning back in time, Bourke (1989) who explored the internal and external determinants of profitability in 90 banks from 1972 to 1981 over 12 countries or territories in Europe, North America and Australia provided the same conclusion with Ruziqa (2013). Nevertheless, there remain a lot more studies that concluded the relationship between liquidity risk and profitability is positive. For instance, Molyneux and Thornton (1992), who examined determinants of bank profitability on a sample of European banks, 671 for 1986, 1,063 for 1987, 1,371 for 1988 and 1,108 for 1989 across eighteen countries as well as Demirgüç-Kunt, Laeven, and Levine (2003) who investigated the influence of bank regulations, concentration, inflation and national institutions on bank net interest margins with the sample on over 1,400 banks across 72 countries from 1995 to 1999 , both argued that highly liquid banks with high amount of cash and government securities can receive relatively low interest income than the less liquid ones. Under competitive market for deposit, greater liquid tends to be negatively correlated with profitability.

\section{Research Methodology}

\subsection{Sample and Model Selection}

Some 16 listed commercial banks in Vietnam during the period from 2010 to 2017, when the Vietnamese economy became more stable after the recovery from the crisis a few years ago, were put into our analysis. The purpose of this research is to identify the reactions of Vietnamese banks in two aspects, regulatory (Capital Adequacy Ratio) and Performance. To this end, the paper will estimate following system equations:

Capital adequacy equation:

CARit $=\beta 1+\beta 2$ ROAit $+\beta 3$ TOBINQit $+\beta 4$ CREDITGit $+\beta 5$ GDPGRit $+\beta 6$ ETDit $+\beta$ LLTDit $+\beta 8$ CTIit $+\beta 9$ INFit + $\beta 10 \mathrm{LOG}(\mathrm{TA})$ it $+\varepsilon 1$ it

Performance equation:

ROEit $=\beta 11+\beta 12$ CARit $+\beta 13$ TOBINQit $+\beta 14$ CREDITGit $+\beta 15$ GDPGit $+\beta 16$ ETDit $+\beta 17$ LTDit $+\beta 18$ CTIit $+\beta 19$ INFit $+\beta 20$ LOG(TA)it $+\varepsilon 2$ it

Where:

- Subscripts i denote 16 Vietnamese commercial banks, $\mathrm{t}$ denotes the time period $(\mathrm{t}=2010$ to 2017$), \beta$ is the parameters to be estimated and $\varepsilon$ is the error term.

- Capital Adequacy Ratio (CAR)

- Return on Equity (ROE)
- Return on Assets (ROA)

- Tobin's Q (TOBINQ): market value of a company divided by its assets' replacement cost.

- Credit growth (CREDITG): Change in Outstanding Loans over Ending Outstanding Loans

- GDP growth (GDPGR)

- Equity-to-Deposit ratio (ETD): Shareholders Equity over Deposits from Customers

- Loan-to-Deposits ratio (LTD): Outstanding Loans over Customers' Deposits

- Cost-to-Income ratio (CTI): numerator includes all operating expenses (i.e. non-interesting expenses) and denominator covers net interest income, fee income, trading income and other operating income

- Inflation (INF): Annual inflation rate

- Bank Size (LOG(TA)): Natural Logarithm of Total Assets at the end of every financial year

In this paper, simultaneous equation systems are estimated by Ordinary Least Squares (OLS). In other word, capital adequacy equation and performance equation have a joint dependence between Capital Adequacy Ratio and Performance.

Appendix 2 briefly describes the variables included in the above equations in terms of Notation, Measurement and hypotheses on sign of relationship with dependent variable CAR and ROE.

\subsection{Descriptive Statistics}

There are 128 observations from 16 commercial banks over eight years. The table below provides the descriptive statistics with the mean, medium, maximum, minimum, standard deviation and number of observations (see Table 1).

Table 1 demonstrates the statistical information about 128 variables of 16 Vietnamese commercial banks during the period from 2010 to 2017. First of all, by looking at average CAR ratio of 14.64 percent, it is clearly seen that Vietnamese banks tended to keep considerably higher capital than the minimum of eight percent required by Basel Committee. Interestingly, despite the considerably high mean of CAR ratio, the median is only at nearly 13 percent, which means that the main outliers stay at high end of the distribution. Specifically, these abnormal banks are KLB and SGB with average CAR ratio of 22.86 and 22.32 percent, respectively. Besides, EIB, VIB and SeABank are three of the outliers with Capital ratio over 15 percent. The rationale for this fact might be believed that almost all these banks are small-cap financial institutions with less competitiveness compared to big banks such as BID, VCB, etc.

On the other hand, ROE has a mean value of $11.3 \%$ and median of $10.14 \%$. This indicates that there still exist big gaps of profitability among banks. Interestingly, despite the 
Table 1: Descriptive statistics

\begin{tabular}{|c|c|c|c|c|c|}
\hline & Mean & Median & Maximum & Minimum & Std. Dev. \\
\hline CAR & 0.1463 & 0.1304 & 0.5492 & 0.0802 & 0.0617 \\
\hline ROA & 0.0092 & 0.0079 & 0.0554 & 0.0001 & 0.0072 \\
\hline ROE & 0.1130 & 0.1013 & 0.9060 & 0.0008 & 0.1029 \\
\hline TOBINQ & 0.9736 & 0.9921 & 1.5824 & 0.1249 & 0.1582 \\
\hline CREDITG & 0.2141 & 0.1967 & 1.253 .7 & -0.2333 & 0.1992 \\
\hline CTI & 0.5534 & 0.5421 & 1.151 .0 & 0.2395 & 0.1723 \\
\hline ETD & 0.1133 & 0.0952 & 0.4038 & 0.0009 & 0.0715 \\
\hline LIQUID & 0.0202 & 0.0140 & 0.1333 & 0.0039 & 0.0205 \\
\hline LTD & 0.7443 & 0.7270 & 1.391 .6 & 0.2540 & 0.2400 \\
\hline NPL & 0.0520 & 0.0217 & 2.085 .0 & 0.0050 & 0.2429 \\
\hline PLL & 0.0142 & 0.0122 & 0.1036 & 0.0063 & 0.0092 \\
\hline LOG(TA) & 18.6665 & 18.8236 & 20.9069 & 15.9227 & 1.1277 \\
\hline
\end{tabular}

same high level of CAR ratios as just mentioned, KLB's and SGB's ROE in average show a big difference of $9.67 \%$.

The same issue seems to appear in data of Credit Growth (CREDITG) as well. With the mean of 21.4 percent, median is only 19.68 percent, maximum credit growth among banks is 125.37 percent and minimum value is -017.53 percent, there are still several outliers with extremely high credit growth rate in accordance with their low capital reserve ratio. However, SeABank is one remarkable exception as it is considered one of the smaller banks with relatively large capital reserve ratio, but this bank still carries the highest average credit growth rate at 41.95 percent (Appendix 1) and even the maximum value at 125.37 percent. SeABank has faced a difficult time with negative credit growth rate until 2012, which began to rebound across the industry and by 2013, it had reached a record high growth for the past eight years.

Turning to Equity/Deposits ratio (ED), it is also noteworthy that this variable's large Standard Deviation value of 6.39 percent is only five percent lower than the mean value. ED fluctuated with a wide range from 5.13 to 40.38 percent, which belongs to KienLongBank. KienLongBank and SaiGonBank are also two of the 14 samples bearing highest ED ratios and this seems to be consistent with their high CAR ratio, showing the trend of less lending among banks with high liquidity level but low stableness of capital structure. Likewise, indicating the identical trend with ED variable, Loans/Deposits (LTD) witnesses a huge gap between minimum value of 28.92 percent and maximum value of 139.16 percent, average value and median are 78.64 and 75.65 , respectively.

In addition to the descriptive statistic table, the Correlation Matrix table in Appendix 1 will give the information about the correlation between variables. Overall, CAR has positive correlations with CREDITG, EQUITYDEPOSIT, INF, NPL and ROA but negative ones with CTI, GDPG, LIQUID, LTD, PLL, ROE, LOG(TA) and TOBINQ.

\section{Empirical Results}

Before running the initial equations, a pre-test is performed, which comes to a result of insignificant relations between CAR and Inflation and between ROE and LTD. For that reason, the variable INF was eliminated from the capital adequacy equation while the variable LTD was removed from the performance equation (see Appendix 3 and 4).

Initial Regression Models:

$\mathrm{CAR}=\mathrm{C}(1)+\mathrm{C}(2) * \mathrm{ROA}+\mathrm{C}(3)^{*} \mathrm{TOBINQ}+$ $\mathrm{C}(4) *(\mathrm{CREDITG}+\mathrm{GDPGR})+\mathrm{C}(5) * \mathrm{ETD}+\mathrm{C}(6) * \mathrm{LTD}+$ $\mathrm{C}(7) * \mathrm{CTI}+\mathrm{C}(8) * \mathrm{LOG}(\mathrm{TA})$

$\mathrm{ROE}=\mathrm{C}(9)+\mathrm{C}(10) * \mathrm{CAR}+\mathrm{C}(11)^{*} \mathrm{TOBINQ}+$ $\mathrm{C}(12) *(\mathrm{CREDITG}+\mathrm{GDPGR})+\mathrm{C}(13) * \mathrm{ETD}+\mathrm{C}(14) * \mathrm{INF}+$ $\mathrm{C}(15) * \mathrm{CTI}+\mathrm{C}(16) * \mathrm{LOG}(\mathrm{TA})$

Substituted Coefficients:

$\mathrm{CAR}=0.4857-1.9013 * \mathrm{ROA}-0.0577 * \mathrm{TOBINQ}+$ $0.02913 *(\mathrm{CREDITG}+\mathrm{GDPG})+0.5891 * \mathrm{ETD}-0.0411 * \mathrm{LTD}$ - $0.05307 *$ CTI $-0.0150 *$ LOG(TA)

$\mathrm{t}$-Statistic of the substituted coefficients are 5.0971, $-3.3554,-2.6128,1.8679,7.0709,-2.6280,-2.3126$ and -3. 0487 respectively. R-squared $=0.702505$, Adjusted R-squared $=0.685151$ 
$\mathrm{ROE}=-0.05830-0.5585 * \mathrm{CAR}+0.0201 * \mathrm{TOBINQ}+$ $0.0716 *(\mathrm{CREDITG}+\mathrm{GDPG})+0.4344 * \mathrm{ETD}+0.4465 * \mathrm{INF}$ $-0.1098 * \mathrm{CTI}+0.0106 * \mathrm{LOG}(\mathrm{TA})$

t-Statistic of the substituted coefficients are -0.2119 , $-2.4196,0.3302,1.6911,2.0001,2.6897,-1.9094$ and 0.8292 respectively. R-squared $=0.233090$, Adjusted R-squared $=$ 0.188354

The equations above demonstrated the outcome by running Eviews to generate the equations of CAR and ROE with other eight independent variables by simultaneous equation model (SEM). However, these models still have problems with insignificant variables so the results of the model selections are not really reliable. Therefore, Wald Test is critical to be applied in order to verify the problem of redundant variables in all three models and improve the models' quality. The Wald Test's result is as follow (see Table 2):

The table above exhibits the Wald Test result on model. With probability of Chi-square at 0.9233 , which is much higher than 5 percent of significant level, there is not enough statistical evidence to reject Null Hypothesis. On the other word, the coefficients $\mathrm{C}(9)$ and $\mathrm{C}(11)$ are statistically insignificant in the model, or the constant variable and Tobin-Q should be dropped out of the ROE equation.

\subsection{Final Regression Models}

After dropping some of the insignificant variables, the new regression models are as follow:

Estimated $(\mathrm{CAR})=0.4857-1.9013 * \mathrm{ROA}-$ $0.0577 *$ TOBINQ $+0.0291 *($ CREDITG + GDPG $)$ $+0.5891 *$ ETD $-0.0411 *$ LTD $-0.05307 *$ CTI $0.0150 *$ LOG(TA)

t-Statistic of the substituted coefficients are 5.0971, $-3.3554,-2.6128,1.8679,7.0709,-2.6280,-2.3126$ and -3.0487 respectively. R-squared $=0.702505$, Adjusted R-squared $=0.685151$

Table 2: Wald Test's results

\begin{tabular}{|l|c|c|c|}
\hline Test Statistic & Value & Df & Probability \\
\hline Chi-square & 0.159501 & 2 & 0.9233 \\
\hline Null Hypothesis: C(9)=0, C(11)=0 & \\
\hline Null Hypothesis Summary: & \\
\hline Normalized Restriction (= 0) & Value & Std. Err. \\
\hline C (9) & -0.058301 & 0.275149 \\
\hline C (11) & 0.020053 & 0.060726 \\
\hline Restrictions are linear in coefficients. \\
\hline
\end{tabular}

\author{
Estimated $(\mathrm{ROE})=-0.6056 * \mathrm{CAR}+$ \\ $0.07418 *(\mathrm{CREDITG}+\mathrm{GDPG})+0.4508 * \mathrm{ETD}+0.4430 * \mathrm{INF}$ \\ $-0.1156 * \mathrm{CTI}+0.0087 *$ LOG(TA)
}

$\mathrm{t}$-Statistic of the substituted coefficients are -3.1963 , $1.7995,2.5844,2.7152,-2.4812$ and 4.9526 respectively. R-squared $=0.232360$, Adjusted R-squared $=0.200899$

It is interesting to note that, with new structure of variables, the models show significance in all new variables at $\alpha$ levels of $1 \%, 5 \%$ or $10 \%$.

From the two final equations, it can be seen that Credit growth, GDP growth and Equity-to-Deposit ratio all have positive effects on CAR and ROE, while Cost-to-Income ratio displays negative relationships with two dependent variables. Thereby, it can be concluded that, to meet the wishes of both banks and regulators, that is to increase both profits and capital, banks should increase Equity-to-Deposit ratio and reduce Cost-to-Income ratio. At the same time, an increase in credit growth and GDP growth also boosted CAR and profitability to rise.

Generally, regarding elements influencing CAR ratio, we have ROA, Tobin' Q, Loan-to-Deposit ratio, Cost-to-Income ratio and Bank size have significantly negative effects but Credit growth, GDP growth and Equity-to-Deposit ratio have positive impacts. On the other hand, in Performance equation, CAR ratio and Cost-to-Income ratio negatively affect $\mathrm{ROE}$ while Credit growth, GDP growth, Equity-to-Deposit ratio and Inflation show the positive effects. Of all the variables tested in Performance equation, Tobin' $\mathrm{Q}$ is an insignificant one.

\subsection{Capital Adequacy Equation}

In the capital adequacy equation, Equity/Deposits ratio is statistically significant, displaying a positive effect as expected above. The formula of Equity/Deposits ratio is representative of liquidity risk and it has Equity on numerator and Deposits from customers in denominator. Based on the empirical result, it can be explained as when Equity increases, although the Risk-Weighted Assets increase, reserved capital also raised with higher proportion, leading to a higher CAR ratio. Additionally, as mentioned by Vale (2011), Capital Adequacy Ratio and Equity/Deposits ratio have an interactive relationship with each other.

On the other hand, Loans-to-Deposits ratio (LTD) negatively influences CAR, which means that a higher LTD ratio indicates a lower level of liquidity. When Outstanding Loans rise, Total Assets and Risk-Weighted Assets increase as well, forcing CAR to reduce. For easier explanation, when LTD is lower, liquidity position is more ensured and CAR might increase. The higher the liquidity position is, the lower the bankruptcy possibilities are and the lower the Riskweighted Assets are, causing CAR to be higher. 


\subsection{Performance Equation}

The final performance equation pointed out a positive relationship between bank size and ROE. This result is consistent with the findings by Halkos and Salamouris (2004) and Limam (2002), who concluded that a larger bank can have better chance of survival and improvement under the intensely competitive environment.

The finding for a substantially positive relationship between inflation and performance is revealed by the model, which is confirmed by a number of studies. According to Athanasoglou, Brissimis and Delis (2008), if inflation is predicted, excessive income can be achieved because of the asymmetric information between the bank and the customer, therefore banks will be able to adjust interest rates for loans and deposits appropriately to get higher interest gap.

In terms of capital adequacy-profitability relationship, both models indicate the significantly negative relationship between CAR and performance. This negative capital adequacy and profitability relationship is reinforced by Modigliani and Miller's Capital Structure Irrelevance Theory (1958), where Berger (1995) clarified that, when the debt ratio is replaced by equity, CAR rises leading to risk mitigation and therefore the market rate of return on securities will decline.

\section{Conclusion}

From the regulators' perspectives, higher capital adequacy ratio brings good effects and safety for the banking sector and the nation. On the commercial banks' side, they always give top priority to profitability instead of capital or stability. Therefore, the purpose of this paper is to conduct simultaneous models that can explain the relationship between capital adequacy ratio and profitability in Vietnamese banks as well as imply the common elements affecting Capital Adequacy Ratio and ROE over the period 2010-2017 using the simultaneous equation systems. Thanks to this method, the endogenous issues between these two variables can be controlled.

The result of simultaneous negative relationship between capital and performance provide recommendations for banks to improve market performance by managing and make use of capital in an effective and efficient way. It is not always best to keep a large amount of capital or only making highquality loans since, even though this method generates high CAR for banks, it produces lower profits. Besides, to maintain an adequate level of capital, besides raising equity's capital, banks also can reduce risk-weighted assets.

On the other hand, banks are demanded to know about determinative factors of their capital ratio and take proper actions to maintain an adequate and suitable capital ratio as these factors change. For instance, if a bank forecasts that there will be a dramatic growth in inflation in the upcoming period, it should narrow its lending and invest in activities for more capital. These actions should not be discarded as they help financial institutions not only beautify financial records and indicators in the eyes of customers and investors, but also help keep the bank safe in all circumstances. To do so, banks can carry out research on their own or rely on other papers' results and recommendations. However, it should be borne in mind that, for different banking sectors in different nations, capital may vary and the applications cannot be consistently exercised for every bank, so that banks should smartly consider the factors, which are suitable and necessary.

\section{References}

Adeusi, S., Kolapo, F., \& Aluko, A. (2014). Determinants of Commercial Banks' Profitability Panel Evidence from Nigeria. International Journal of Economics, Commerce and Management, 2(12), 1-18. [Online Journal] Available at: http:// ijecm.co.uk/wp-content/uploads/2014/12/21228.pdf

Al-Tamimi, K. and Fakhri, S. (2013). Determinants of Capital Adequacy in Commercial Banks of Jordan an Empirical Study. International Journal of Academic Research in Economics and Management Sciences, 2(4), 44-58.

Altunbas, Y., Carbo, S., Gardener, E. P. M., \& Molyneux, P. (2007). Examining the Relationships between Capital, Risk and Efficiency in European Banking. European Financial Management, 13(1), 49-70.

Amadeo, K. (2018). The 2008 Financial Crisis A Look at the Causes, Costs and Weighing the Chances of It Happening Again. Retrieved September 25, 2019, from https://www. thebalance.com/2008-financial-crisis3305679

Athanasoglou, P., Brissimis, S., \& Delis, M. (2008). Bank-specific, Industry-specific and Macroeconomic Determinants of Bank Profitability. Journal of International Financial Markets, Institution and Money, 18(2), 121-136.

Australian Bankers' Association. (2012). Bank Profits - Frequently Asked Questions. Retrieved September 15, 2019, from www. ausbanking.org.au/images/uploads/ArticleDocuments/192/ Fact $\% 20$ Sheet $\% 20$ Banks\%20Profits\%20FAQs.pdf

Bami, B. (2014). Internal and External Factors Affecting Banking Profitability: Evidence from Albanian Banking Sector. Tirana, Albania: Master of Science, Epoka University.

Bank for International Settlements. (2018). History of the Basel Committee. Retrieved October 25, 2019, from https://www.bis. org/bcbs/history.htm

Barrios, V. E., \& Blanco, J. M. (2003). The effectiveness of bank capital adequacy regulation: A theoretical and empirical approach. Journal of Banking \& Finance, 27(10), 1935-1958.

Berger, A. (1995). The Relationship between Capital and Earning in Banking. Journal of Money, Credit, and Banking, 27, 432-456. 
Berger, A., \& Bonaccorsi, D. (2006). Capital structure and firm performance: A new approach to testing agency theory and an application to the banking industry. Journal of Banking \& Finance, 30, 1065-1102.

Bourke, P. (1989). Concentration and Other Determinants of Bank Profitability in Europe, North America, and Australia. Journal of Banking and Finance, 13(1), 65-79.

Lee, C. C., Ning, S. L., \& Lee, C. C. (2015). How Does Bank Capital Affect Bank Profitability and Risk? Evidence from China's WTO Accession. China \& World Economy, 23(4), 19-39.

Dao, B. T. T., \& Nguyen, D. P. (2020). Determinants of Profitability in Commercial Banks in Vietnam, Malaysia and Thailand. Journal of Asian Finance, Economics and Business, 7(4), 133143. https://doi.org/10.13106/jafeb.2020.vol7.no4.133

Dao, T. T. B., \& Nguyen, T. N. (2016). Determinant factors of capital adequacy ratio in Vietnamese commercial banks. $V N U$ Journal of Science: Economics and Business, 32(2), 49-58.

Demirgüç-Kunt, A., Laeven, L., \& Levine, R. (2003). The Impact of Bank Regulations, Concentration, and Institutions on Bank Margins. World Bank Policy Research Working Paper (No. 3030).

Ha, D. V. (2019). The Interactive Relationship between Credit Growth and Operational Self-Sustainability of People's Credit Funds in Mekong Delta Region of Vietnam. Journal of Asian Finance, Economics and Business, 6(3), 55-65. https://doi. org/10.13106/jafeb.2019.vol6.no3.55

Halkos, G. E., \& Salamouris, D. S. (2004). Efficiency measurement of the Greek Commercial banks with the use of financial ratios: A Data Envelopment Analysis Approach. Management Accounting Research, 15(2), 201-224. http://dx.doi. org/10.1016/j.mar.2004.02.001

Limam, I. (2002). A comparative study of GCC banks technical efficiency. Working Paper (No. 0119), Economic Research Forum. Egypt.

McConnell, C. R., Brue, S. L., \& Flynn, S. M. (2015). Economics: Principles, problems, and policies (20th Ed.). Boston: McGraw Hill Learning Solutions.

Modigliani, F., \& Miller, M. H. (1958). The Cost of Capital, Corporation Finance and the Theory of Investment (Vol. 48): JSTOR.
Molyneux, P., \& Thornton, J. (1992). Determinants of European bank profitability: A Note. Journal of Banking and Finance, $16,1173-1178$.

Muriithi, J., \& Muigai, R. (2017). Quantitative analysis of Operational Risk and Profitability of Kenyan Commercial Banks using Cost Income Ratio. IOSR Journal of Economics and Finance, 8(3), 76-83.

Nuviyanti and Anggono, A. H. (2014). Determinants of Capital Adequacy Ratio (CAR) in 19 Commercial Banks. Journal of Business and Management, 3(7), 752-764.

Olarewaju, O. M., \& Akande, J. O. (2016). An Empirical Analysis of Capital Adequacy Determinants in Nigerian Banking Sector. International Journal of Economics and Finance, 8(12), 132-142.

Perry, P. (1992). Do Banks Gain or Lose from Inflation? Journal of Retail Banking, 14, 25-30.

Pham, T. X. T., \& Nguyen, N. A. (2017). Determinants of Capital Adequacy Ratio: The Case of the Vietnamese Banking System in the Period 2011-2015. VNU Journal of Science: Economics and Business, 33(2), 49-58.

Tran T. Q. G., \& Vu. T. T. A. (n.d.). Vietnam - Politically driven mock compliance. Global Economic Governance Programme, Blavatnik School of Government, University of Oxford.

Revell, J. (1979). Inflation and financial institutions. London Financial Times Ltd.

Rime, B. (2001). An Alternative View on Regulatory Distortions in a Competitive Financial Services Industry. Journal of Financial Services Research, 19(11), 27-38,

Ruziqa, A. (2013). The Impact of Credit and Liquidity Risk on Bank Financial Performance: The Case of Indonesian Conventional Bank with Total Asset above 10 trillion Rupiah. International Journal of Economic Policy in Emerging Economies, 6(2), 93- 106.

Vale, B. (2011). Effects of Higher Equity Ratio on a Bank's Total Funding Costs and Lending. Norges Bank (The central bank of Norway), No.10. 